\title{
Faktor-faktor yang mempengaruhi nasabah menabung di lembaga perkreditan desa (LPD) kawasan pemukiman dan pariwisata
}

\author{
Factors that influence customers to save at village credit institutions (LPD) in residential and \\ tourism areas
}

\author{
Ni Made Dhita Kusuma Wahyuni $i^{1{ }^{*}}$, I Nyoman Gede Ustriyana ${ }^{1)}$, Gede Mekse Korri Arisena ${ }^{1)}$ \\ ${ }^{1}$ Progam Studi Agribisnis, Fakultas Pertanian, Universitas Udayana, Bali. \\ *Email Korespondensi: dhitakusumawahyuni17@gmail.com
}

Informasi artikel: Dikirim: 31/05/2020 Ditinjau: 31/05/2020 Disetujui: 24/09/2020

Copyright (c) 2020 Ni Made Dhita Kusuma Wahyuni, I Nyoman Gede Ustriyana, Gede Makse Korri Arisena

\begin{abstract}
Local credit institutions (LPD) are non-bank financial institutions manager by local governments and are autonomous and oriented to strengthen the economic and socio-cultural life of indigenous peoples in Bali. This study aims to analyze what factors influence the customer's decision to save in the LPD of residential and tourism areas and analyze what are the dominant factors that influence the customer's decision to save in the LPD of residential areas and tourism. The data used using primary data as the main data by distributing questionnaires in each LPD as many as 50 respondents. The data obtained were processed using SPSS and SEM-PLS analysis techniques. The results showed that factors such as the environment of the customer's residence significantly influence the interest in saving in the LPD of residential areas and security guarantees affect the interest in saving customers in the LPD of the tourism area. Keywords: Savings interest, $L P D$, partial least square (PLS).
\end{abstract}

ABSTRAK: Lembaga Perkreditan Desa (LPD) merupakan lembaga keuangan bukan bank yang diselenggarakan oleh pemerintah daerah dan bersifat otonom dan diorientasikan untuk menguatkan kehidupan ekonomi dan sosial budaya masyarakat adat di Bali. Penelitian ini bertujuan menguji variabel Promosi $\left(X_{1}\right)$, pelayanan $\left(X_{2}\right)$, Kredibilitas Lembaga $\left(X_{3}\right)$, Kesesuaian dengan Prinsip Tri Hita Karana $\left(X_{4}\right)$ Aksesbilitas $\left(X_{5}\right)$, Lingkungan Tempat Tinggal Nasabah $\left(X_{6}\right)$, Kepercayaan $\left(X_{7}\right)$, Pengetahuan $\left(X_{8}\right)$, Lokasi Lembaga $\left(X_{9}\right)$, dan Jaminan Keamanan $\left(X_{10}\right)$ serta pengaruhnya terhadap minat menabung di LPD. Data yang digunakan menggunakan data primer sebagai data utama dengan menyebar kuisioner di masing-masing LPD sebanyak 50 responden. Data yang diperoleh, diolah menggunakan SPSS dan teknik analisis SEM-PLS. Hasil penelitian menunjukkan bahwa faktor-faktor seperti lingkungan tempat tinggal nasabah berpengaruh signifikan terhadap minat menabung di LPD kawasan pemukiman dan jaminan keamanan mempengaruhi minat menabung nasabah di LPD kawasan pariwisata.

Kata kunci: Minat menabung, LPD, partial least square (PLS)

Sitasi: Wahyuni, N. M. D. K., Ustriyana, I. N. G., \& Arisena, G. M. K. (2020). Faktor-faktor yang mempengaruhi nasabah menabung di lembaga perkreditan desa (LPD) kawasan pemukiman dan pariwisata. AGROMIX, 11(2), 227-240. https://doi.org/10.35891/agx.v11i2.1967

\section{PENDAHULUAN}

Kegiatan perekonomian suatu Negara lembaga keuangan. Lembaga keuangan selalu berkaitan dengan lalu lintas pembayaran,yang di mana industri perbankan ataupun lembaga keuangan lainnya mempunyai peran yang sangat signifikan sebagai urat nadi sistem perekonomian. Di era modern ini masyarakat mulai menyadari akan kebutuhan berfungsi sebagai lembaga intermediasi antara pihak yang mempunyai kelebihan dana (surplus of funds) dengan pihak-pihak yang kekurangan dan yang membutuhkan dana (lack of funds) (Wiliasih \& Shadrina, 2017). Selain itu Ismail 
(2010) menyatakan bahwa Lembaga keuangan mempunyai fungsi utama dana dari masyarakat dalam bentuk simpanan dan menyalurkannya dalam bentuk kredit dan memberikan pelayanan dalam bentuk jasa perbankan.

Lembaga Perkreditan Desa (LPD) merupakan lembaga keuangan bukan bank yang diselenggarakan oleh pemerintah daerah dan bersifat otonom dan diorientasikan untuk menguatkan kehidupan ekonomi dan sosial budaya masyarakat adat (Ayu dkk., 2014). Sejalan dengan pendapat tersebut Kumbara (2010) menyatakan bahwa Lembaga Perkreditan Desa (LPD) juga mempunyai peran sebagai lembaga yang berperan untuk meningkatkan kesejahteraan rakyat melalui pembangunan ekonomi kerakyatan, dan juga sebagai sumber pendapatan asli desa adat. LPD sebagai lembaga keuangan diharapkan mampu melayani dan meningkatkan perekonomian masyarakat sesuai dengan tujuan pendirian tersebut. Untuk itu LPD harus mampu meningkatkan minat nasabah dalam menyimpan dananya. Untuk itu perlunya keterampilan khusus yang dimiliki oleh pegawai atau staf, sehingga nasabah merasa yakin akan bank atau lembaga keuangan yang dipilihnya (Wahyudi dkk., 2017). Berdasarkan Data Badan Pusat Statistik (BPS) Provinsi Bali tahun 20142018 jumlah kepadatan penduduk di Provinsi Bali menunjukkan peningkatan setiap tahunnya.

Tabel 1. Kepadatan Penduduk Menurut Kabupaten/Kota di Bali 2014-2018

\begin{tabular}{lrrrrr}
\hline Kabupaten/Kota & \multicolumn{5}{c}{ Total (ribu jiwa) } \\
\cline { 2 - 6 } Regency/Municipality & \multicolumn{1}{c}{$\mathbf{2 0 1 4}$} & $\mathbf{2 0 1 5}$ & $\mathbf{2 0 1 6}$ & $\mathbf{2 0 1 7}$ & \multicolumn{2}{c}{$\mathbf{2 0 1 8}$} \\
\hline Jembrana & 321 & 323 & 325 & 327 & 329 \\
Tabanan & 427 & 430 & 432 & 435 & 437 \\
Badung & 1440 & 1472 & 1505 & 1537 & 1569 \\
Gianyar & 1333 & 1345 & 1358 & 1369 & 1381 \\
Klungkung & 555 & 558 & 561 & 563 & 566 \\
Bangli & 451 & 454 & 456 & 459 & 461 \\
Karangasem & 484 & 487 & 489 & 492 & 494 \\
Buleleng & 471 & 474 & 476 & 479 & 482 \\
Denpasar & 6758 & 6892 & 7022 & 7155 & 7283 \\
Provinsi Bali & 11816 & 12435 & 12624 & 12816 & 13002 \\
\hline
\end{tabular}

Sumber : Sensus Penduduk Badan Pusat Statistik Provinsi Bali (2019)

Pada Tabel 1 terlihat bahwa Kota Tentang Penataan Ruang menyatakan bahwa Denpasar menempati urutan pertama kawasan budidaya yang memiliki nilai strategis kepadatan penduduk tertinggi pada tahun 2018 provinsi dapat berupa kawasan pemukiman, yaitu 7283 ribu jiwa dan urutan kedua kawasan kehutanan, kawasan pertanian, kepadatan penduduk terjadi di Kabupaten kawasan pertambangan, kawasan dengan jumlah 1569 ribu jiwa. Berdasarkan perindustrian, dan kawasan pariwisata (Dinan pasal 23 ayat (1) UU Nomor 26 Tahun 2007 Pekerjaan Umum [DPU], 2007). Kota Denpasar 
memiliki nilai strategis sebagai kawasan pemukiman, sedangkan Kabupaten Badung memiliki nilai strategis sebagai kawasan pariwisata. Berdasarkan data Badan Pusat Statistik Provinsi Bali tercatat kunjungan wisatawan mancanegara yang menginap di Kabupaten Badung meningkat dari tahun 20142018 mencapai 67\%. Dengan besarnya penghunian kamar hotel di Kabupaten Badung

Tabel 2. Perkembangan total penabung pada LPD Desa Pakraman Padangsambian dan LPD Desa Adat Kuta tahun 2016-2018

\begin{tabular}{ccc}
\hline Tahun & LPD desa pakraman padangsambian (orang) & LPD desa Adat Kuta (orang) \\
\hline 2016 & 9.964 & 16.208 \\
2017 & 10.794 & 16.803 \\
2018 & 11.764 & 16.856 \\
\hline
\end{tabular}

Sumber : LPLPD Kota Denpasar dan LPLPD Kabupaten Badung

Berdasarkan Tabel 2 jumlah nasabah yang menabung pada LPD Desa Pakraman Padangsambian dan LPD Desa Adat Kuta meningkat tiap tahunnya. Tercatat pada tahun 2016 LPD Desa Pakraman Padangsambian memiliki total nasabah yang menabung sebesar 9.964 orang meningkat pada tahun 2018 sebesar 11.764 orang. Tercatat total nasabah yang menabung pada LPD Desa Adat Kuta sebesar 16.208 orang pada tahun 2016 dan meningkat pada pada tahun 2018 sebesar 16.856 orang. Perbedaan jumlah penabung yang terdapat di LPD Desa Pakraman Padangsambian dan LPD Desa Adat Kuta disebabkan oleh banyak faktor. Berdasarkan tabel tersebut terlihat bahwa minat menabung nasabah relatif tinggi di LPD.
Adapun tujuan dari penelitian ini adalah untuk menganalisis karakteristik responden yang menabung di LPD kawasan pemukiman dan pariwisata, untuk menganalisis perbandingan faktor apa saja yang mempengaruhi keputusan nasabah untuk menabung di LPD kawasan pemukiman dan pariwisata dan menganalisis perbandingan faktor dominan apa yang mempengaruhi keputusan nasabah untuk menabung di LPD kawasan pemukiman dan pariwisata.

\section{MOTODE}

\section{Lokasi dan waktu penelitian}

Penelitian ini akan dilakukan di dua kabupaten di Provinsi Bali, yaitu di kawasan Kabupaten Badung dan Kota Denpasar. Lembaga Perkreditan Desa dipilih secara sengaja (purposive sampling) yaitu LPD Desa 
Pakraman Padangsambian dan LPD Desa Adat Kuta. Alasan pemilihan lokasi di LPD Desa Pakraman Padangsambian dan LPD Desa Adat Kuta dikarenakan LPD tersebut memiliki aset terbesar di kecamatan masing-masing. Pelaksanaan waktu penelitian dilakukan mulai Januari 2020 sampai dengan Maret 2020.

\section{Metode dan teknik analisis data}

Metode pengumpulan data dalam penelitian ini berupa metode survey yang dilakukan dengan cara menyebar kuesioner dan wawancara. Populasi dalam penelitian ini adalah nasabah LPD Desa Pakraman Padangsambian dan LPD Desa Adat Kuta. Dalam penelitian menggunakan Metode secara Probability Sampling. Yang di mana penelitian ini ditetapkan dengan teknik accidental sampling. Sugiyono (2010) menyatakan bahwa accidental sampling yaitu cara memperoleh sampel berdasarkan siapa saja nasabah yang kebetulan ditemui pada saat melakukan penelitian yang diambil di lokasi penelitian. Pengambilan sampel ditetapkan menurut Roscue dalam Sugiyono (2009) yang menyatakan bahwa ukuran sampel yang layak dalam analisis adalah minimal 30 sampel. Berdasarkan hal tersebut jumlah sampel yang digunakan dalam penelitian ini yaitu 100 sampel, di mana masing-masing sampel di bagi sebanyak 50 sampel pada LPD Desa Pakraman Padangsambian dan 50 sampel pada LPD Desa
Adat Kuta. Selanjutnya dalam menentukan sampel di masing-masing LPD diperoleh dengan mendata langsung nasabah yang datang menabung ke LPD, dengan menunggu di lobi LPD sampai jumlah responden 50 orang terpenuhi di masing-masing LPD.

\section{Variabel penelitian dan metode analisis data}

Variabel-variabel yang terdapat dalam penelitian ini terdiri dari variabel dependen yaitu Minat Menabung $\left(Y_{1}\right)$, dan variabel independen meliputi tingkat Promosi $\left(\mathrm{X}_{1}\right)$, pelayanan $\left(X_{2}\right), \quad$ Kredibilitas Lembaga $\left(X_{3}\right)$, Kesesuaian dengan Prinsip Tri Hita Karana $\left(\mathrm{X}_{4}\right)$ Aksesbilitas $\left(X_{5}\right)$, Lingkungan Tempat Tinggal Nasabah $\left(X_{6}\right)$, Kepercayaan $\left(X_{7}\right)$, Pengetahuan $\left(X_{8}\right)$, Lokasi Lembaga $\left(X_{9}\right)$, dan Jaminan Keamanan $\left(\mathrm{X}_{10}\right)$. Sejalan dengan penelitian Fadilah (2019) Penelitian ini menggunakan Partial Leat Square (PLS) untuk menganalisis data yang diperoleh, dan skala yang digunakan dalam kuesioner adalah skala likert. Kemudian data yang diperoleh menggunakan kuesioner diuji kualitas datanya menggunakan Sofware Statistical Pacge for the Social Science (SPSS) versi 22 dan Microsoft Excel 2013 untuk input datanya. Lalu hasilnya akan dipresentasikan dalam bentuk tabel. Setelah dilakukan uji kualitas data, selanjutnya dilakukan pengujian statistik menggunakan Partial Leat Square (PLS) dan uji hipotesis. 


\section{HASIL DAN PEMBAHASAN}

\section{Karakteristik responden}

Karakteristik responden dibedakan dengan melihat jenis pekerjaan yang di mana mayoritas responden di LPD kawasan pemukiman bekerja sebagai PNS, sedangkan di LPD kawasan pariwisata adalah wirausaha. Rata-rata pendapatan mayoritas responden di LPD kawasan pemukiman pada interval $\mathrm{Rp}$ 3.000.000 - Rp 4.000.000 perbulan, dan kawasan pariwisata berada pada interval $\mathrm{Rp}$ 5.000.000-Rp10.000.000 perbulan. Pada LPD kawasan pemukiman nasabah paling banyak menabung dengan intensitas sebulan sekali dengan nominal rata-rata $>$ Rp100.000 sebesar 42\%. Pada LPD kawasan pariwisata nasabah paling banyak menabung dengan intensitas sebulan sekali dengan nominal rata-rata $>\mathrm{Rp}$
100.000 sebesar 46\%. Hal ini dikarenakan nasabah lebih memilih untuk mengumpulkan uangnya terlebih dahulu kemudian disetorkan pada waktu tertentu kepada teller (Prena \& Kustina, 2020; Saputra dkk., 2019).

\section{Analisis data}

\section{Evaluasi model pengukuran (outer model)}

Model pengukuran atau Outer model merupakan evaluasi model untuk melihat hubungan antara variabel dengan indikatorindikatornya. Ukuran refleksi indikator dengan konstruknya dikatakan tinggi jika memiliki nilai loading factor lebih dari 0,7 (Chin, 1998 dalam Ghozali, 2014). Diagram jalur hasil pengolahan data dengan bantuan software Smart-PLS (Partial Least Square) dapat dilihat pada Gambar 1 dan Gambar 2.

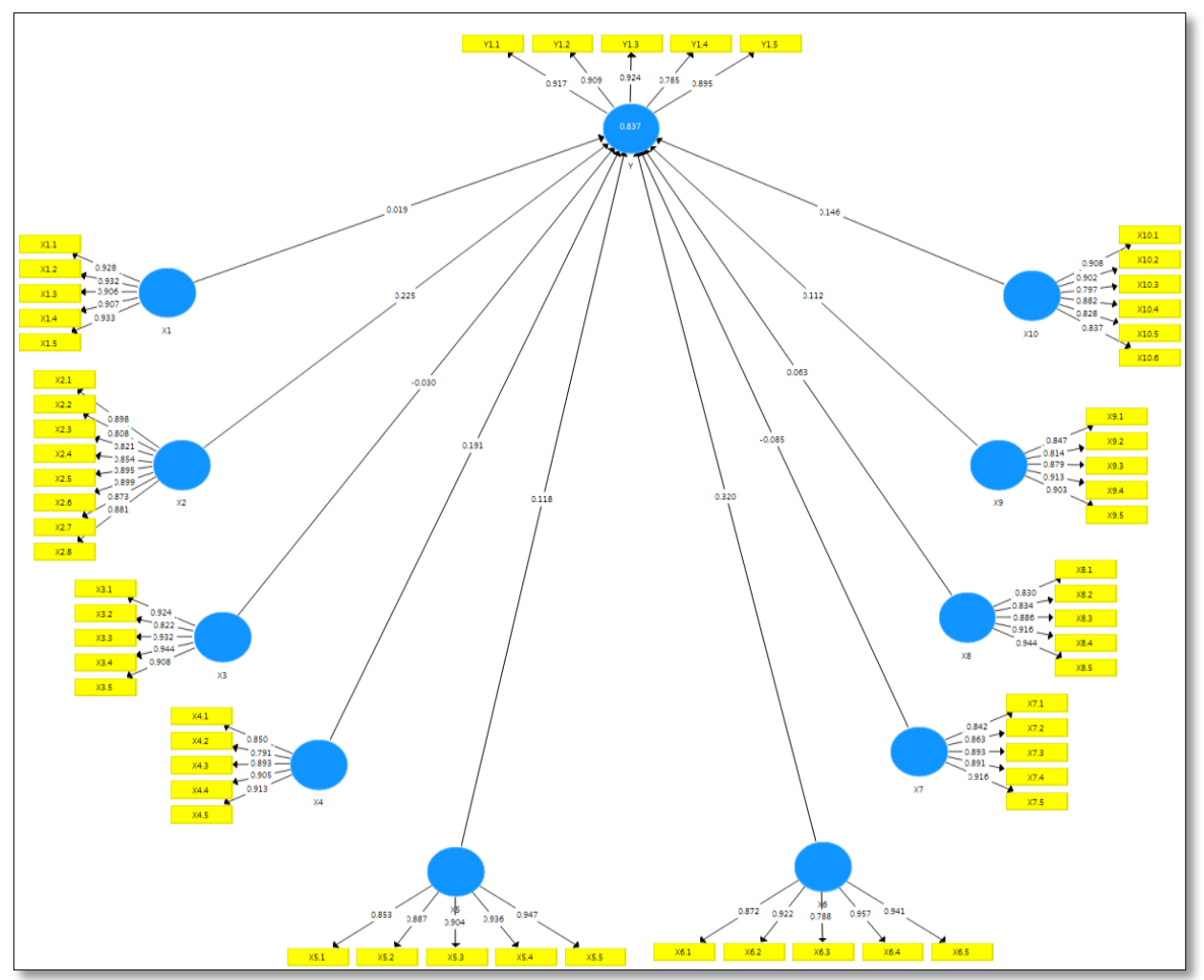

Gambar 1. Hasil Outer model faktor-faktor yang mempengaruhi minat menabung nasabah di LPD kawasan pemukiman dengan software Smart-PLS (Partial Least Square) 


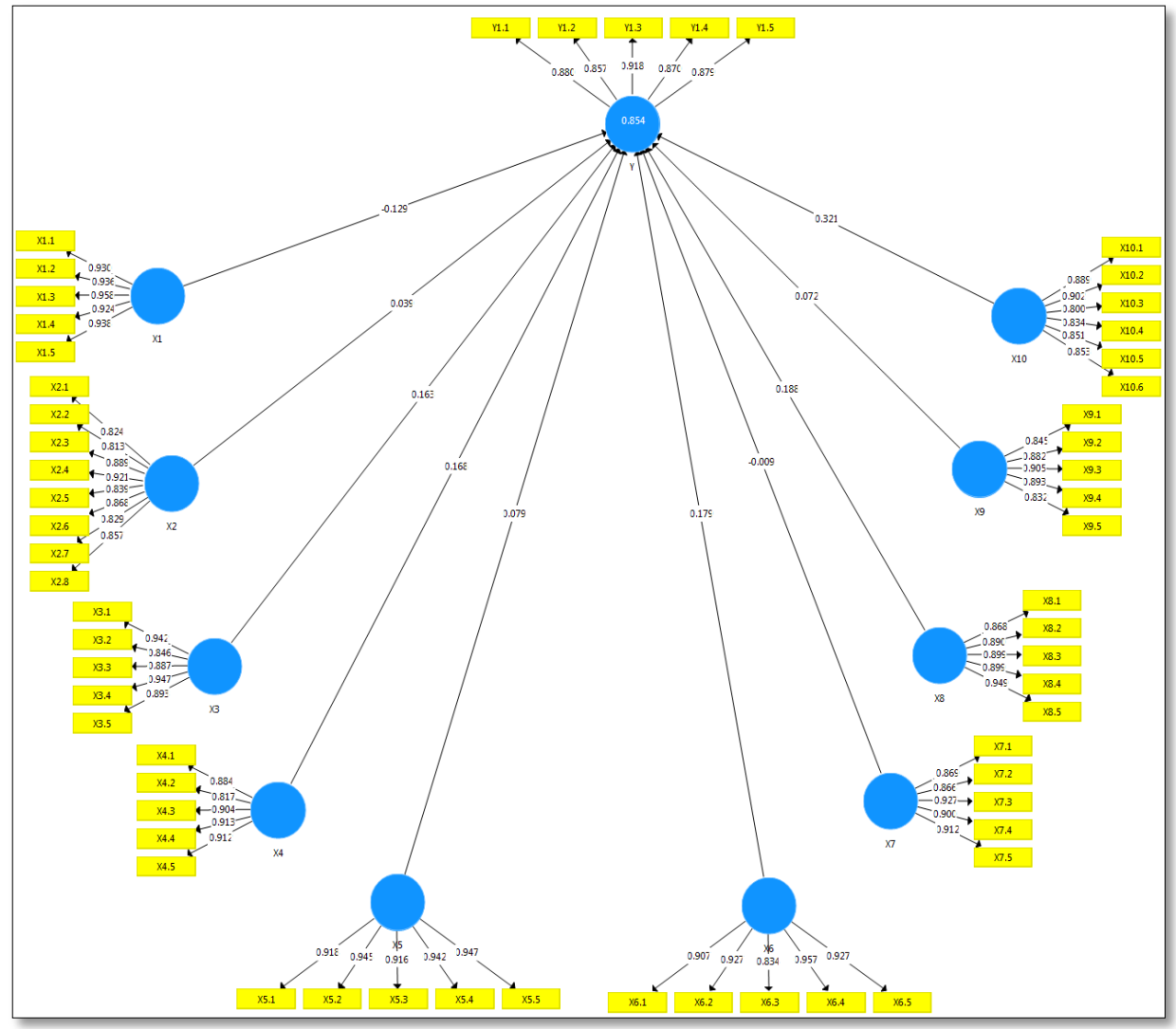

Gambar 2. Hasil outer model faktor-faktor yang mempengaruhi minat menabung nasabah di LPD kawasan pariwisata software Smart-PLS (Partial Least Square)

Model pada Gambar 1 dan Gambar 2 menunjukkan bahwa terdapat 59 indikator yang memiliki loading faktor lebih dari 0,7. Maka nilai di atas menunjukkan korelasi antara indikator dengan konstruknya.

1. Pengujian validitas model

a. Pengujian untuk convergent validity yaitu dengan melihat nilai Average Variance Extraxted (AVE) pada model PLS. Syarat model memiliki validitas yang baik apabila masing-masing variabel laten memiliki (AVE) di atas 0,5 Berdasarkan analisis, nilai AVE dari masing-masing variabel laten memiliki nilai di atas 0,5 dan dapat dikatakan bahwa model PLS dalam penelitian ini memenuhi syarat convergent validity yang baik.

b. Pengujian discriminant validity dilakukan dengan prinsip bahwa pengukur-pengukur (manifest variabel) konstruk atau variabel yang berbeda seharusnya tidak berkolerasi tinggi (Ghozali, 2014). Penelitian menggunakan nilai cross loading untuk mengukur discriminant validity dan setiap variabel laten harus memiliki nilai lebih dari 0,7. Setiap indikator memiliki cross loading lebih dari 0,7 untuk variabel laten yang diukur dibandingkan dengan indikator variabel lainnya. Indikator pada promosi, pelayanan, kredibilitas lembaga, kesesuaian dengan 
prinsip Tri Hita Karana, lokasi lembaga, lingkungan tempat tinggal nasabah, aksestibilitas, kepercayaan, pengetahuan, jaminan keamanan dan minat menabung memiliki korelasi yang lebih besar pada laten sendiri dari pada korelasi ke laten lainnya, sehingga model memenuhi syarat discriminant validity.
2. Pengujian reabilitas variabel

Pengujian reliabilitas terhadap variabel yang digunakan untuk membuktikan keakuratan, konsistensi, dan ketepatan instrument dalam mengukur konstruk. Uji reliabilitas yang pertama yaitu mengukur composite reliability dan cronbach'alpha terhadap keenam variabel laten dan model dikatakan riabel memiliki nilai di atas 0,7.

Tabel 3.Nilai reliabilitas kawasan pemukiman

\begin{tabular}{lrr}
\hline \multicolumn{1}{c}{ Variabel laten } & Cronbach's alpha & Composite reliability \\
\hline Promosi & 0,956 & 0,966 \\
Pelayanan & 0,953 & 0,960 \\
Kredibilitas Lembaga & 0,946 & 0,959 \\
Kesesuaian dengan prinsip Tri Hita Karana & 0,920 & 0,940 \\
Aksesbilitas & 0,945 & 0,958 \\
Lingkungan Tempat Tinggal Nasabah & 0,939 & 0,954 \\
Kepercayaan & 0,929 & 0,946 \\
Pengetahuan & 0,929 & 0,946 \\
Lokasi Lembaga & 0,921 & 0,941 \\
Jaminan Keamanan & 0,930 & 0,945 \\
Minat Menabung & 0,932 & 0,949 \\
\hline
\end{tabular}

Tabel 4.Nilai reliabilitas kawasan pariwisata

\begin{tabular}{lrr}
\hline \multicolumn{1}{c}{ Variabel laten } & Cronbach's alpha & Composite reliability \\
\hline Promosi & 0,965 & 0,973 \\
Pelayanan & 0,947 & 0,956 \\
Kredibilitas Lembaga & 0,944 & 0,957 \\
Kesesuaian dengan prinsip Tri Hita Karana & 0,932 & 0,948 \\
Aksesbilitas & 0,963 & 0,971 \\
Lingkungan Tempat Tinggal Nasabah & 0,949 & 0,961 \\
Kepercayaan & 0,938 & 0,953 \\
Pengetahuan & 0,942 & 0,956 \\
Lokasi Lembaga & 0,926 & 0,942 \\
Jaminan Keamanan & 0,928 & 0,945 \\
Minat Menabung & 0,932 & 0,949 \\
\hline
\end{tabular}

Berdasarkan Tabel 3 dan Tabel 4 hasil analisis menunjukkan semua konstruk memiliki reliabilitas yang baik, akurat dan konsisten. Terlihat memenuhi syarat dengan nilai composite reliability dan cronbach's alpha pada setiap konstruk laten memiliki nilai di atas 0,7. 
Analisis evaluasi model structural (inner model)

Model struktural atau inner model adalah model yang menggambarkan signifikansi hubungan dan pengaruh antar variabel laten.

\section{Penilaian R-Square}

Inner model pertama dimulai dengan melihat nilai $R$-square untuk setiap variabel laten endogen Perubahan nilai $R$-square dapat menjelaskan pengaruh variabel laten eksogen (promosi, pelayanan, kredibilitas lembaga, kesesuaian dengan prinsip Tri Hita Karana, lokasi lembaga, lingkungan tempat tinggal nasabah, aksestibilitas, kepercayaan, pengetahuan, dan jaminan keamanan) terhadap variabel laten endogen (minat menabung). Berdasarkan hasil analisis $R$-square di kawasan pemukiman variabel endogen minat menabung memiliki nilai sebesar 0,837 dan di kawasan pariwisata memiliki nilai 0,854 dapat

Tabel 5. Path coefficient kawasan pemukiman

\begin{tabular}{lrrrr}
\hline & Original sample (O) & $\begin{array}{c}\text { Standard deviation } \\
\text { (STDEV) }\end{array}$ & $\begin{array}{c}\text { T statistics } \\
\text { (|O/STDEV |) }\end{array}$ & P values \\
\hline X1 -> Y & 0,019 & 0,207 & 0,091 & 0,928 \\
X2 -> Y & 0,225 & 0,157 & 1,434 & 0,152 \\
X3 -> Y & $-0,030$ & 0,195 & 0,153 & 0,879 \\
X4 -> Y & 0,191 & 0,140 & 1,361 & 0,174 \\
X5 -> Y & 0,118 & 0,122 & 0,961 & 0.337 \\
X6 -> Y & 0,320 & 0,151 & 2,123 & 0,034 \\
X7 -> Y & $-0,085$ & 0,164 & 0,518 & 0,605 \\
X8 -> Y & 0,063 & 0,129 & 0,490 & 0,624 \\
X9 -> Y & 0,112 & 0,129 & 0,867 & 0,386 \\
X10 -> Y & 0,146 & 0,156 & 0,940 & 0,347 \\
\hline
\end{tabular}


Tabel 6. Path coefficient kawasan pariwisata

\begin{tabular}{lrrrr}
\hline & Original sample (O) & $\begin{array}{r}\text { Standard deviation } \\
\text { (STDEV) }\end{array}$ & $\begin{array}{c}\text { T statistics } \\
(\text { /O/STDEV I) }\end{array}$ & P values \\
\hline X1 -> Y & $-0,129$ & 0,188 & 0,684 & 0,494 \\
X2 -> Y & 0,039 & 0,170 & 0,232 & 0,817 \\
X3 - Y & 0,163 & 0,180 & 0,904 & 0,366 \\
X4 - Y & 0,168 & 0,159 & 1,061 & 0,289 \\
X5 -> Y & 0,079 & 0,183 & 0,433 & 0,665 \\
X6 -> Y & 0,179 & 0,181 & 0,993 & 0,321 \\
X7 -> Y & $-0,009$ & 0,128 & 0,073 & 0,942 \\
X8 -> Y & 0,188 & 0,104 & 1,805 & 0,072 \\
X9 - Y & 0,072 & 0,126 & 0,574 & 0,566 \\
X10 -> Y & 0,321 & 0,150 & 2,148 & 0,032 \\
\hline
\end{tabular}

Hasil bootstrapping pada Tabel 5 menunjukkan hanya variabel lingkungan tempat tinggal nasabah yang memiliki pengaruh signifikan (t-statistik $>$ t-tabel yaitu $1,96$ serta $p$-value $<0,05)$ dengan signifikansi 5\%. Hasil penelitian ini sejalan dengan studi yang dilakukan Bari'ah dan Zaenal Abidin, (2013) yang menyatakan bahwa tempat tinggal nasabah menjadi salah satu faktor penting dalam menentukan minat menabung nasabah. Dalam penelitiannya juga menyatakan bahwa minat yang tinggi untuk menabung juga disebabkan oleh adanya kebutuhan akan area operasional bank yang strategis, yang diketahui bahwa nasabah memilih menabung di LPD karena lokasinya dekat dengan tempat tinggal. Sedangkan untuk variabel promosi, pelayanan, kredibilitas lembaga, kesesuaian dengan prinsip Tri Hita Karana, lokasi lembaga, aksestibilitas, kepercayaan, pengetahuan, jaminan keamanan tidak berpengaruh secara signifikan. Tabel 6 menunjukkan hanya variabel jaminan keamanan yang memiliki pengaruh signifikan (t-statistik > t-tabel yaitu 1,96 serta $p$-value
$<0,05)$ dengan signifikansi $5 \%$. Hasil penelitian ini sejalan dengan penelitian Setyawan dan Japarianto (2014) yang menyatakan bahwa bahwa jaminan rasa aman terbukti berpengaruh signifikan terhadap minat menabung di Bank Danamon. Sedangkan untuk variabel promosi, pelayanan, kredibilitas lembaga, kesesuaian dengan prinsip Tri Hita Karana, lokasi lembaga, lingkungan tempat tinggal nasabah, aksestibilitas, kepercayaan, pengetahuan tidak berpengaruh secara signifikan. Pengujian hipotesis tentang promosi, pelayanan, kredibilitas lembaga, kesesuaian dengan prinsip Tri Hita Karana, lokasi lembaga, lingkungan tempat tinggal nasabah, aksestibilitas, kepercayaan,pengetahuan, dan jaminan keamanan terhadap minat menabung di LPD kawasan pemukiman pariwisata dilakukan dengan mengamati nilai path coefficient.

\section{Pengujian hipotesis}

Besarnya pengaruh laten eksogen terhadap laten endogen dapat dilihat dari nilai 
koefisien tiap jalur sehingga dapat dijelaskan pengaruhnya sebagai berikut.

1. Pengaruh promosi terhadap minat menabung nasabah di LPD kawasan pemukiman dan pariwisata dapat sebagai berikut.

a. Kawasan pemukiman

Meskipun berpengaruh positif namun variabel promosi tidak berpengaruh signifikan dilihat dari nilai $p$-value sebesar 0,928 >0,05. Dengan demikian hal ini tidak sejalan dengan penelitian yang dilakukan oleh Hutabarat, (2010) yang menyatakan bahwa promosi berpengaruh terhadap keputusan masyarakat untuk menjadi nasabah pada bank syariah.

b. Kawasan pariwisata

Berdasarkan hasil pengolahan data variabel promosi tidak berpengaruh signifikan dilihat dari nilai $p$-value sebesar 0,494 >0,05.

2. Pengaruh pelayanan terhadap minat nasabah di LPD kawasan pemukiman dan pariwisata sebagai berikut.

a. Kawasan pemukiman

Variabel pelayanan tidak berpengaruh signifikan dilihat dari nilai tp-value sebesar 0,152 >0,05. Dengan demikian hal ini tidak sejalan dengan penelitian yang dilakukan oleh (Surip dkk., 2013) yang menyatakan bahwa pelayanan berpengaruh signifikan terhadap minat menabung

b. Kawasan pariwisata

Variabel pelayanan tidak berpengaruh signifikan dilihat dari nilai p-value sebesar $0,817>0,05$.

3. Pengaruh kredibilitas lembaga terhadap minat nasabah di LPD kawasan pemukiman dan pariwisata sebagai berikut.

a. Kawasan pemukiman

Variabel kredibilitas lembaga tidak berpengaruh signifikan dilihat dari nilai $p$-value sebesar 0,879>0,05. Dengan demikian hal ini tidak sejalan dengan penelitian yang dilakukan oleh Anggraeni (2016) di mana penelitian tersebut menyatakan bahwa kredibilitas bank berpengaruh pengaruh positif tidak signifikan terhadap minat nasabah.

b. Kawasan pariwisata

Variabel I kredibilitas lembaga berpengaruh positif sebesar 16,3\% terhadap variabel minat menabung nasabah. Meskipun berpengaruh positif namun variabel kredibilitas lembaga tidak berpengaruh signifikan dilihat dari nilai $p$-value sebesar $0,366>0,05$.

4. Pengaruh kesesuaian dengan prinsip Tri Hita Karana terhadap minat nasabah di LPD kawasan pemukiman dan pariwisata sebagai berikut. 
a. Kawasan pemukiman

Variabel kesesuaian dengan prinsip Tri Hita Karana tidak berpengaruh signifikan dilihat dari nilai $p$-value sebesar 0,174 >0,05.

b. Kawasan pariwisata

Variabel kesesuaian dengan prinsip Tri Hita Karana tidak berpengaruh signifikan dilihat dari nilai $p$-value sebesar 0,289 >0,05.

5. Pengaruh aksesbilitas terhadap minat nasabah di LPD kawasan pemukiman dan pariwisata sebagai berikut.

a. Kawasan pemukiman

Variabel aksesbilitas tidak berpengaruh signifikan dilihat dari nilai $p$-value sebesar $0,337>0,05$.

b. Kawasan pariwisata

Variabel aksesbilitas tidak berpengaruh signifikan dilihat dari nilai $p$-value sebesar $0,665>0,05$.

6. Pengaruh lingkungan tempat tinggal nasabah terhadap minat nasabah di LPD kawasan pemukiman dan pariwisata sebagai berikut.

a. Kawasan pemukiman

Variabel lingkungan tempat tinggal nasabah berpengaruh terhadap minat menabung dan memiliki nilai positif sebesar 0,320, yang berarti mencerminkan lingkungan tempat tinggal nasabah berpengaruh terhadap minat menabung sebesar $32 \%$. Hasil penelitian ini sejalan dengan studi yang dilakukan Bari'ah dan Zaenal Abidin (2013) yang menyatakan bahwa tempat tinggal nasabah menjadi salah satu faktor penting dalam menentukan minat menabung nasabah.

b. Kawasan pariwisata

Variabel lingkungan tempat tinggal nasabah tidak berpengaruh signifikan dilihat dari $p$-value sebesar 0,321 yang > 0,05 .

7. Pengaruh kepercayaan terhadap minat nasabah di LPD kawasan pemukiman dan pariwisata sebagai berikut.

a. Kawasan pemukiman

Variabel kepercayaan tidak berpengaruh signifikan dilihat dari nilai p-value sebesar 0,605 >0,05.

b. Kawasan pariwisata

Variabel kepercayaan tidak berpengaruh signifikan dilihat dari nilai p-value sebesar 0,942>0,05.

8. Pengaruh pengetahuan terhadap minat nasabah di LPD kawasan pemukiman dan pariwisata sebagai berikut.

a. Kawasan pemukiman

Variabel pengetahuan tidak berpengaruh signifikan dilihat dari nilai $p$-value sebesar $0,624>0,05$. Hasil penelitian ini sejalan dengan studi yang dilakukan Abhimantra, (2013) yang menyatakan bahwa tempat tinggal nasabah menjadi salah satu faktor 
penting dalam menentukan minat menabung nasabah.

b. Kawasan pariwisata

Variabel pengetahuan tidak berpengaruh signifikan dilihat dari nilai p-value sebesar 0,072 >0,05.

9. Pengaruh lokasi lembaga terhadap minat nasabah di LPD kawasan pemukiman dan pariwisata sebagai berikut.

a. Kawasan pemukiman

Variabel lokasi lembaga tidak berpengaruh signifikan dilihat dari nilai p-value sebesar 0,386 >0,05.

b. Kawasan pariwisata

Variabel lokasi lembaga tidak berpengaruh signifikan dilihat dari nilai $p$-value sebesar 0,566 >0,05.

10. Pengaruh jaminan keamanan terhadap minat nasabah di LPD kawasan pemukiman dan pariwisata sebagai berikut.

a. Kawasan pemukiman

Variabel jaminan keamanan tidak berpengaruh signifikan dilihat dari nilai $p$-value sebesar 0,347>0,05.

b. Kawasan pariwisata

Berdasarkan hasil pengolahan data variabel eksogen jaminan keamanan berpengaruh signifikan terhadap variabel endogen minat menabung dengan nilai t-statistik sebesar 2,148 lebih besar dari nilai (t-tabel signifikansi $5 \%=1,96)$. Variabel jaminan keamanan berpengaruh terhadap minat menabung dan memiliki nilai positif sebesar 0,321, yang berarti mencerminkan jaminan keamanan berpengaruh terhadap minat menabung sebesar $32,1 \%$.

Perbandingan faktor dominan yang mempengaruhi keputusan nasabah untuk menabung di LPD kawasan pemukiman dan pariwisata

Variabel dominan artinya variabel laten yang memiliki pengaruh paling besar terhadap variabel laten endogen yang dipengaruhinya. Pada kawasan pemukiman faktor yang paling dominan yaitu lingkungan tempat tinggal nasabah (X6). Lingkungan tempat tinggal nasabah memiliki pengaruh dominan terhadap minat menabung artinya lingkungan tempat tinggal dijadikan pertimbangan utama nasabah dibandingkan variabel lainnya. Sejalan dengan pendapat Nurtjahjanti dan Abidin (2013) bahwa nasabah memilih menabung karena bank atau lembaga keuangan dekat dengan lokasi yang dekat dengan kantor dan tempat tinggal nasabah (Khan \& Fasih 2014). Sedangkan untuk di LPD kawasan pariwisata variabel jaminan keamanan (X10) memiliki pengaruh dominan untuk mempengaruhi minat menabung nasabah. Temuan dalam penelitian ini mendukung penelitian Setyawan dan Japarianto (2014) yang menjelaskan bahwa jaminan keamanan yang dirasakan nasabah semakin meningkat maka minat menabung juga semakin meningkat dan juga ketika jaminan 
dana keamanan yang ditabungkan rendah maka nasabah cenderung menolak untuk menggunakan layanan tabungan bank (Madjid, 2013; Stouthuysen dkk., 2013). Jaminan keamanan memiliki pengaruh dominan terhadap keputusan menabung artinya jaminan keamanan dijadikan pertimbangan utama nasabah dibandingkan variabel lainnya (Uts dkk., 2012).

\section{KESIMPULAN}

Berdasarkan analisis dan pembahasan yang telah dilakukan, maka dapat disimpulkan terdapat pengaruh signifikan antara konstruk lingkungan tempat tinggal nasabah terhadap minat menabung di LPD kawasan pemukiman. Karena lokasi kantor yang dekat dengan lingkungan tempat tinggal nasabah mendasari atau menambah minat menggunakan produkproduk tabungan di LPD.

Terdapat pengaruh signifikan antara konstruk jaminan keamanan terhadap minat menabung nasabah di LPD kawasan pariwisata. Karena jaminan keamanan merupakan hal mendasar dan paling penting dalam menentukan nasabah untuk menabung. Jaminan keamanan yang dirasakan nasabah semakin meningkat maka minat menabung juga semakin meningkat dan juga ketika jaminan dana keamanan yang ditabungkan rendah maka nasabah cenderung menolak untuk menggunakan layanan tabungan.
Variabel dominan yang mempengaruhi minat menabung nasabah di LPD kawasan pemukiman yaitu lingkungan tempat tinggal nasabah, sedangkan untuk di LPD kawasan pariwisata yaitu variabel jaminan keamanan.

\section{DAFTAR PUSTAKA}

Abhimantra, A., Maulina, A. R., \& Agustianingsih, E. (2013). Analisis faktorfaktor yang mempengaruhi nasabah (mahasiswa) dalam memilih menabung pada bank syariah. Prosiding PESAT, 5, 89.

Anggraeni, T. (2016). Pengaruh sosial, kredibilitas bank, dan harapan kinerja terhadap minat nasabah menggunakan internet banking bank cimb niaga di Surabaya [Doctoral dissertation]. STIE Perbanas Surabaya.

Ayu, G., Suarni, P., Trupalupi, I. E., \& Haris, I. A. (2014). Analisis faktor yang mempengaruhi keputusan nasabah dalam pengambilan kredit pada LPD (lembaga perkreditan desa) desa pakraman manggissari. Jurnal Pendidikan Ekonomi Undiksha, 4(1). http://dx.doi.org/10.23887/jjpe.v4i1.302 3

Badan Pusat Statistik [BPS]. (2018). Kepadatan penduduk menurut kabupaten/kota di bali 2014-2018. Badan Pusat Statistik Bali. https://bali.bps.go.id/statictable/2018/06 /28/115/kepadatan-penduduk-menurutkabupaten-kota-di-bali-2010-2019.html

Badan Pusat Statistik [BPS]. (2018). Tingkat penghunian kamar hotel berbintang menurut bulan di kabupaten badung tahun 2014-2018. Badan Pusat Statistik Bali.

https://badungkab.bps.go.id/subject/16/ pariwisata.html

Bari'ah, B. A., Abidin, Z., \& Nurtjahjanti, H. (2009). Hubungan antara kualitas layanan bank dengan minat menabung nasabah PT BRI kantor cabang Ungaran [Doctoral dissertation]. Universitas 
Diponegoro.

Chin, W. W. (1998). The partial least squares approach to structural equation modeling. Modern methods for business research, 295(2), 295-336.

Dinan Pekerjaan Umum [DPU] (2007). Undangundang no. 26 tahun 2007 tentang penataan ruang. Dinas Pekerjaan Umum.

Ghozali, I. (2014). SEM metode alternatif dengan partial least square. Badan Penerbit Universitas Diponogoro.

Hutabarat, S. (2010). Faktor-faktor yang mempengaruhi keputusan masyarakat menjadi nasabah bank syariah di pekanbaru. Jurnal Tabarru' : Islamic Banking and Finance, 2(1), 39-49. https://doi.org/10.25299/jtb.2019.vol2(1) .3442

Ismail, I. (2010). Manajemen perbankan. Jakarta: Kencana.

Khan, M. M., \& Fasih, M. (2014). Impact of service quality on customer satisfaction and customer loyalty: Evidence from banking sector. Pakistan Journal of Commerce and Social Sciences (PJCSS), 8(2), 331-354. https://doi.org/10.1111 /j.1467-629X.2011.00466.x

Kumbara, K. (2010). Kontruksi wacana ajeg bali dalam relasi kuasa. Universitas Udayana Bukit Jimbaran.

Madjid, R. (2013). Customer trust as relationship mediation between customer satisfaction and loyalty at Bank Rakyat Indonesia (BRI) Southeast Sulawesi. The international journal of engineering and science, 2(5), 48-60.

Prena, G. D., \& Kustina, K. T. (2020). Relationship Of Intellectual Capital To Dynamic Capabilities In Village Credit Institutions. GIS Business, 15(1), 95-108.

Roscoe, R. (2006). Metode Penelitian Bisnis. Jakarta: Salemba Empat.

Saputra, K. A. K., Jayawarsa, A. K., \& Atmadja, A. T. (2019). Resurrection as a fading implication of accountability in financial management for village credit institution. International Journal of Business, Economics and Law, 19(5), 258268.

Setyawan, \& Japarianto (2014). Analisa Pengaruh Kepercayaan, Jaminan rasa aman, dan aksesbilitas terhadap minat menabung nasabah bank Danamon di Surabaya. Jurnal Strategi Pemasaran, 2(1), 1-8.

Stouthuysen, K., Teunis, I., Reusen, E., \& Slabbinck, H. (2018). Initial trust and intentions to buy: The effect of vendorspecific guarantees, customer reviews and the role of online shopping experience. Electronic Commerce Research and Applications, 27, 23-38. https://doi.org/10.1016/j.elerap.2017.11. 002

Sugiyono, S. (2010). Metode penelitian pendidikan pendekatan kuantitatif, kualitatif, dan R\&D. Alfabeta.

Surip, D. T. (2013). Pengaruh kualitas produk tabungan dan kualitas layanan terhadap minat menabung kembali di CIMB Niaga (studi kasus PT. Bank CIMB Niaga Tbk. Bintaro). Jurnal MIX, 6(3), 356-368.

Utz, S., Kerkhof, P., \& Van Den Bos, J. (2012). Consumers rule: How consumer reviews influence perceived trustworthiness of online stores. Electronic Commerce Research and Applications, 11(1), 49-58. https://doi.org/ 10.1016/j.elerap.2011.07.010

Wahyudi, R., Carmelina, R., Indartono, K., \& Handani, S. W. (2017). Analisis minat menabung masyarakat terhadap tabungan pada PT. Bank Negara Indonesia (Persero) Tbk. Cabang Bukittinggi. Probisnis, 10(1), 52-64.

Wiliasih, R., \& Shadrina, F. (2017). Faktor dominan yang memengaruhi keputusan nasabah untuk menabung di Bank Syariah, BPRS, dan KSPPS. Nisbah: Jurnal Perbankan Syariah, 3(2), 442. https://doi.org/10.30997/jn.v3i2.911 